\title{
Survey on the prevalence of Listeria monocytogenes in Belgian artisanal cheeses
}

\author{
Amaury Gérard ${ }^{(1)}$, Soundous El-Hajjaji ${ }^{(1)}$, Els Van Coillie ${ }^{(2)}$, Azeddine Bentaib ${ }^{(3)}$, \\ Georges Daube ${ }^{(4)}$, Marianne Sindic ${ }^{(1)}$ \\ (1) University of Liège - Gembloux Agro-Bio Tech. Laboratory of Quality and Safety of Agro-Food Products. Passage des \\ Déportés, 2. BE-5030 Gembloux (Belgium).Email: amaury.gerard@uliege.be \\ (2) Flanders Research Institute for Agriculture, Fisheries and Food (ILVO). Technology and Food Science Unit. \\ Brusselsesteenweg, 370. BE-9090 Melle (Belgium). \\ (3) Quality Partner S.A. Rue Hayeneux, 62. BE-4040 Herstal (Belgium). \\ (4) University of Liège, Faculty of Veterinary Medicine. FARAH, Food Science Department. Sart-Tilman, B43b. BE-4000 \\ Liège (Belgium).
}

Received 30 October 2019, accepted 4 May 2020, available online 19 May 2020.

This article is distributed under the terms and conditions of the CC-BY License (http://creativecommons.org/licenses/by/4.0)

Description of the subject. Cheese is a vector of Listeria monocytogenes. By default, European Commission imposes its absence in cheese before sales, but fixes $\mathrm{pH}$ and water activity thresholds below which it cannot grow.

Objectives. To study $\mathrm{pH}$ and water activity of Belgian cheeses and the prevalence of L. monocytogenes in these products.

Method. Salt content, $\mathrm{pH}$ and water activity of 134 cheeses were determined. Absence of L. monocytogenes in $25 \mathrm{~g}$ of cheese was also checked.

Results. Three samples had $\mathrm{pH}$ or water activity under threshold values from regulation. Nevertheless, all unripened cheeses were acid in comparison with data from foreign countries. Listeria monocytogenes was isolated from $1.49 \%$ of the samples.

Conclusions. Belgian artisanal cheeses could allow the growth of L. monocytogenes, and the bacterium was isolated from two samples. Further experiments should be performed to understand the fate of the pathogen in these products.

Keywords. Cheese, chemicophysical properties, Listeria monocytogenes, surveys, regulations, Belgium.

Enquête sur la prévalence de Listeria monocytogenes au sein des fromages artisanaux belges

Description du sujet. Le fromage est un vecteur de Listeria monocytogenes. Par défaut, la Commission européenne impose son absence dans le fromage avant la vente, mais fixe des valeurs seuils de $\mathrm{pH}$ et d'activité de l'eau en dessous desquelles elle ne peut se développer.

Objectifs. Étudier le pH et l'activité de l'eau des fromages artisanaux belges et la prévalence de L. monocytogenes au sein de ces produits.

Méthode. La teneur en sel, le pH et l'activité de l'eau de 134 fromages ont été déterminés. L'absence de L. monocytogenes dans $25 \mathrm{~g}$ de fromage a également été vérifiée.

Résultats. Trois échantillons ont présenté une activité de l'eau ou un pH inférieurs aux valeurs seuils proposées par le règlement. Néanmoins, l'ensemble des fromages non affinés étaient acides en comparaison des données relatives aux pays étrangers. Listeria monocytogenes a été isolée dans 1,49\% des échantillons.

Conclusions. Les fromages artisanaux belges pourraient permettre la croissance de L. monocytogenes et la bactérie a été isolée au sein de deux échantillons. Des expériences complémentaires sont nécessaires afin de comprendre le devenir d'une éventuelle contamination de L. monocytogenes dans ce type de produit.

Mots-clés. Fromage, propriété physicochimique, Listeria monocytogenes, enquête, réglementation, Belgique. 


\section{INTRODUCTION}

Each Belgian eats $14.5 \mathrm{~kg}$ of cheese per year (Agriculture et Agroalimentaire Canada, 2018). Cheese can be the vector of Listeria monocytogenes Murray et al., which is responsible for listeriosis, a foodborne disease of which 2,549 cases were reported in Europe in 2018. The same year, the case fatality of listeriosis was $15.6 \%$. This foodborne disease is thus dangerous, especially for people at risk, including neonates, pregnant women and old or immunocompromised people (European Food Safety Authority - European Centre for Disease Prevention and Control, 2019). Considering the risk for food safety, criteria regarding the presence of L.monocytogenes in ready-to-eat foods are strict, especially before sales by the producer (Table 1, European Commission, 2005). This bacterium is known to be able to survive or even to grow into a lot of cheeses, including brie, camembert, cottage cheese, gorgonzola and saint-nectaire (Gérard et al., 2018). Only a small part of cheeses available on the market can be considered as not allowing the growth of L.monocytogenes (category 1.3 from Regulation (E) No $2073 / 2005$, i.e. $\mathrm{pH} \leq 4.4$ or water activity $\left[a_{w}\right] \leq 0.92$ or $\mathrm{pH} \leq 5.0$ and $a_{w} \leq 0.94$ ), namely fresh cheeses with a sufficiently low $\mathrm{pH}$ and hard cheeses with $a_{w}$ under 0.92 . All other cheeses are considered as allowing the growth of the pathogen and belong thus to category 1.2. Consequently, producers must guarantee that L. monocytogenes remains undetected in cheese before it is put on the market (European Commission, 2005). Provided that L. monocytogenes is a ubiquitous bacterium, the latter criterion is not easy to fulfil. The result is an intense pressure on artisanal producers, for which a single presence of the pathogen in cheese can have harmful moral and financial consequences. It seems thus important to focus more on the issue of the presence of L.monocytogenes in Belgian artisanal cheeses. Belgian cheeses, including herve and maquée, remain unstudied. Given the lack of knowledge regarding these products, they cannot be classified with precision into categories from Regulation (EC) No 2073/2005. A first step was to focus on the prevalence of $L$. monocytogenes in Belgian artisanal cheeses. Their $\mathrm{pH}$ and $a_{w}$ were also investigated and put in relation with threshold values from European Regulation.

\section{METHOD}

\subsection{Sampling}

Between January and December 2018, 134 cheeses were sampled in 65 Belgian farmhouses. Each of these farmhouses was visited between one and four times. Animal origin of milk, milk heat treatment, and type of cheese were considered (Table 2). Classification of cheeses was based on texture and ripening, considering unripened soft cheeses (USC), ripened soft cheeses (RSC) and ripened semi-hard/hard cheeses $(\mathrm{SH} / \mathrm{HC})$ (Codex Alimentarius, 2006). As presented in Table 3, the sampling was distributed on the whole year for each type of cheese. Cheeses selection was based on the results of a survey conducted on 130 Belgian artisanal producers (unpublished results). From the same survey, major cheese subtypes were identified. Those are used in Table 2. For USC, considered subtypes were:

- full-fat maquée, a fresh cheese obtained from whole milk after at least $24 \mathrm{~h}$ of lactic curdling and packaged in plastic punnet;

- low-fat maquée, a maquée produced from skimmed milk;

- other unripened cheeses including buttermilk cheese and fresh cheese.

Three main subtypes of RSC were distinguished, namely:

- smear-ripened soft cheeses, unpressed cheeses regularly washed during ripening, resulting in a typical red rind;

- mold-ripened soft cheeses, unpressed cheeses with a typical white rind composed of Penicillium

Table 1. Food safety criteria regarding the presence of Listeria monocytogenes in ready-to-eat food, simplified from Regulation (EC) No 2073/2005 - Critères d'hygiène alimentaire relatifs à la presence de Listeria monocytogenes dans les denrées alimentaires prêtes à être consommées, simplifiés à partir du Règlement (CE) No 2073/2005.

\begin{tabular}{|c|c|c|}
\hline Food category & Limits & Stage where the criterion applies \\
\hline \multirow{2}{*}{$\begin{array}{l}\text { 1.2 Ready-to-eat foods able to support the growth } \\
\text { of Listeria monocytogenes }\end{array}$} & $100 \mathrm{cfu} \cdot \mathrm{g}^{-1}$ & Products placed on the market during shelf-life \\
\hline & Absence in $25 \mathrm{~g}$ & $\begin{array}{l}\text { Before the food has left the immediate control of } \\
\text { the food business operator who has produced it }\end{array}$ \\
\hline $\begin{array}{l}\text { 1.3 Ready-to-eat foods unable to support the } \\
\text { growth of Listeria monocytogenes }\end{array}$ & $100 \mathrm{cfu} \cdot \mathrm{g}^{-1}$ & Products placed on the market during shelf-life \\
\hline
\end{tabular}


Table 2. Sampling plan - Plan d'échantillonnage $(\mathrm{n}=$ 134).

\begin{tabular}{lc}
\hline Factor & Number of samples \\
\hline Type of milk & 105 \\
Bovine & 20 \\
Caprine & 9 \\
Ovine & \\
\hline Milk treatment & 103 \\
Raw & 31 \\
Pasteurised & \\
\hline Type of cheese & 38 \\
USC & 16 \\
Full-fat maquée & 10 \\
Low-fat maquée & 12 \\
Others & 40 \\
RSC & 16 \\
Smear-ripened & 23 \\
Mold-ripened & 1 \\
Blue-veined & 56 \\
SH/HC & 21 \\
Gouda-type & 23 \\
Saint-paulin-type & 12 \\
Others &
\end{tabular}

Province

$\begin{array}{lr}\text { Flanders } & 38 \\ \text { Antwerp } & 8 \\ \text { East Flanders } & 13 \\ \text { Flemish Brabant } & 4 \\ \text { Limburg } & 3 \\ \text { West Flanders } & 10 \\ \text { Wallonia } & 96 \\ \text { Hainaut } & 30 \\ \text { Liège } & 19 \\ \text { Luxemburg } & 13 \\ \text { Namur } & 27 \\ \text { Walloon Brabant } & 7\end{array}$

USC: unripened soft cheeses - pâtes molles non affinées; RSC: ripened soft cheeses - pâtes molles affinées; $\mathrm{SH} / \mathrm{HC}$ : semihard/hard cheeses - pâtes mi-dures/dures. camemberti Thom and/or Geotrichum candidum Link;

- blue-veined cheeses, presenting Penicillium roqueforti Thom in their core.

Considered subtypes of $\mathrm{SH} / \mathrm{HC}$ were:

- Gouda-type cheeses, unpressed semi-hard cheeses surrounded by an artificial coating and ripened for several month;

- Saint-paulin-type cheeses, also known as abbaye, unpressed semi-hard cheeses with a natural rind or surrounded by an artificial coating and ripened for a shorter period (i.e. at least three weeks);

- other $\mathrm{SH} / \mathrm{HC}$ comprising half-cooked and cooked pressed cheeses.

\subsection{Listeria monocytogenes detection and enumeration}

To detect L. monocytogenes, a pre-enrichment step was performed by incubating $25 \mathrm{~g}$ of cheese in half-Fraser broth (Led Techno, Heusden-Zolder, Belgium) for $24 \mathrm{~h}$ at $24^{\circ} \mathrm{C}$, followed by isolation on RAPID'L.mono plates, after incubation at $37^{\circ} \mathrm{C}$ for $24 \mathrm{~h}( \pm 2 \mathrm{~h})$. Suspect colonies were confirmed on Ottaviani and Agosti Agar Listeria (Bio-Rad, Hercules, USA). For enumeration, samples were diluted (1:10) in buffered peptone water (Led Techno, HeusdenZolder, Belgium) and incubated at $20^{\circ} \mathrm{C}$ for $1 \mathrm{~h}$. Then, $100 \mu \mathrm{l}$ and $1 \mathrm{ml}$ of this suspension were spread on RAPID'L.mono plates and incubated at $37^{\circ} \mathrm{C}$ for $24 \mathrm{~h}$ $( \pm 2 \mathrm{~h})$.

\subsection{Chemicophysical analysis}

For all samples, $\mathrm{pH}$ was measured in the core using an InLab Surface Pro-ISM electrode (Mettler Toledo, Colombus, OH, USA) and $a_{w}$ using an Aqualab 4TE water activity meter (Decagon Devices Inc., Pullman, WA, USA). For ripened cheeses, $\mathrm{pH}$ was also measured on the crust. Salt content was determined following ISO 5943:2006 method (International Organization for Standardization, 2006).

Table 3. Monthly distribution of the samplings by type of cheese - Distribution par mois des prélèvements par type de fromage.

\begin{tabular}{lrrrrrrrrrrrr}
\hline Type of cheese & Jan. & Feb. & March & April & May & June & July & Aug. & Sep. & Oct. & Nov. Dec. & Total \\
\hline USC & 1 & 8 & 11 & 0 & 4 & 0 & 5 & 1 & 2 & 2 & 3 & 1 \\
RSC & 6 & 2 & 4 & 2 & 0 & 0 & 4 & 1 & 3 & 6 & 8 & 4 \\
SH/HC & 2 & 4 & 10 & 3 & 2 & 0 & 2 & 5 & 9 & 10 & 4 & 5 \\
\hline
\end{tabular}

USC, RSC, SH/HC: see table 2 - voir tableau 2. 


\section{RESULTS}

Table 4 summarises the chemicophysical analyses performed on the 134 cheese samples. In cores, the $\mathrm{pH}$ range of USC was limited (4.2-4.9) while this was more variable for other categories (Figure 1). Significant differences $(p<0.001)$ were observed between USC and all ripened cheeses. On the surface, $\mathrm{pH}$ was always higher than in the core. Variability of $a_{w}$ was limited but the averages differed significantly between all categories $(p<0.001)$. Salt content was comparable between RSC and SH/HC $(p=0.394)$, while that of USC was significantly lower $(p<0.001)$. Listeria monocytogenes was isolated from two samples, resulting in a prevalence of $1.49 \%$. Both samples were made from contaminated raw milk and were collected in two cheese factories. One of the contaminated samples was a $\mathrm{SH} / \mathrm{HC}$ made from bovine milk $(\mathrm{pH}=$ $\left.5.32, a_{w}=0.98\right)$, with contamination under $10 \mathrm{cfu} \cdot \mathrm{g}^{-1}$. The second sample was a RSC made from ovine milk
$\left(\mathrm{pH}=7.57, a_{w}=0.97\right)$. Contamination level of the latter sample was $4.68 \log _{10} \mathrm{cfu} \cdot \mathrm{g}^{-1}$.

\section{DISCUSSION}

USC had a lower $\mathrm{pH}$ than those commonly reported. Most USC studied in this paper were prepared by adding starters to milk and by maturing this mixture for at least one day, resulting in a $\mathrm{pH}$ between 4.4 and 5.0 (Goudédranche et al., 2001). A majority of available studies focused on Hispanic USC, generally having a pH > 5.0 (Torres-Vitela et al., 2012; Soto Beltran et al., 2015). To our knowledge, only one paper studied acidic USC and reported a prevalence of L. monocytogenes of $0.0 \%$ (Reda et al., 2016). It was also the case during the present study. In comparison, prevalence above $10.0 \%$ is commonly reported in Hispanic USC (Torres-Vitela et al., 2012; Soto Beltran et al., 2015). For other types of cheeses, $\mathrm{pH}$ and $a_{w}$ were similar

Table 4. Chemicophysical characteristics of the collected cheeses (average \pm standard deviation) - Caractéristiques physicochimiques des fromages collectés (moyenne \pm écart-type).

\begin{tabular}{llllll}
\hline Type of cheese & No. of samples & $\mathbf{p H ~ c o r e}^{\mathbf{a}}$ & $\mathbf{p H ~ s u r f a c e}^{\mathbf{a}}$ & $\boldsymbol{a}_{\boldsymbol{w}}{ }^{\mathbf{b}}$ & ${\text { Salt content }(\%)^{\mathbf{c}}}^{\mathbf{c}^{\mathbf{a}}}$ \\
\hline USC & 38 & $4.5 \pm 0.3$ & $/$ & $0.99 \pm 0.01$ & $0.4 \pm 0.4$ \\
RSC & 40 & $5.6 \pm 0.1$ & $6.9 \pm 0.7$ & $0.98 \pm 0.01$ & $1.8 \pm 0.7$ \\
SH/HC & 56 & $5.6 \pm 0.3$ & $6.8 \pm 0.7$ & $0.96 \pm 0.02$ & $1.7 \pm 0.6$ \\
\hline
\end{tabular}

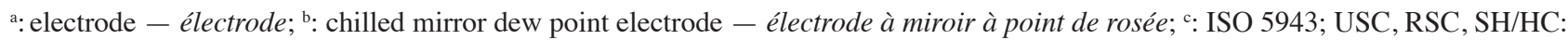
see table 2 - voir tableau 2; /: $\mathrm{pH}$ was not measured on the surface of unripened soft cheese - le pH n'a pas été mesuré à la surface des pâtes molles non affinées.
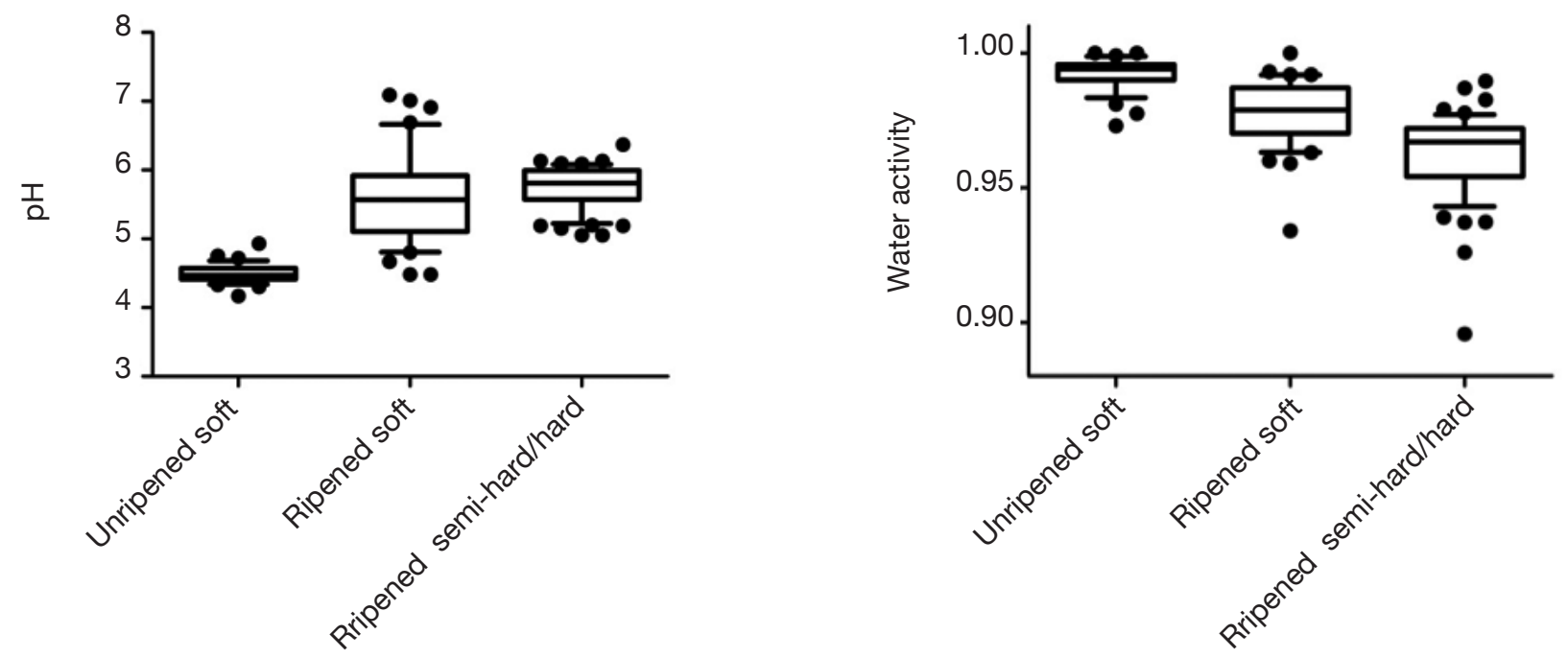

Figure 1. Boxplots of $\mathrm{pH}$ in the core and $a_{w}$ values for unripened soft cheeses, ripened soft cheeses and semi-hard/hard cheeses - Boîtes à moustaches des valeurs de pH (mesuré au centre) et des $\mathrm{a}_{\mathrm{w}}$ pour les pâtes molles non affinées, les pâtes molles affinées et les pâtes mi-dures/dures. 
to data found in the literature, excepting one $\mathrm{SH} / \mathrm{HC}$ with an $a_{w}$ of 0.89 (Gérard et al., 2018). Such a low value has never been reported, although $a_{w} \leq 0.92$ has already been observed (Prencipe et al., 2010). Salt contents measured during this study $(<2 \%$ of salt) were comparable to values provided by Gobbetti et al. (2018) in their book on Italian cheeses. Ibarra-Sanchez et al. (2018) found comparable salt contents for chihuahua, manchego, adobera and queso fresco but sao jorge and cotija were more salted ( $>4.0 \%$ of salt) (Kongo et al., 2006). In vitro, L. monocytogenes is able to grow at salt concentrations such as $10 \%$ (Ferreira et al., 2014). Furthermore, it has already been observed that L. monocytogenes was able to survive for several months in cheese brines with more than $20 \%$ of salt (Larson et al., 1999; Brown et al., 2018). Consequently, salt content of Belgian artisanal cheeses, as well as $\mathrm{pH}$ and $a_{w}$, cannot be considered as barriers to prevent the growth of L. monocytogenes.

The prevalence of L.monocytogenes observed during this study (1.49\% of 134 samples) is higher than data reported by some papers on asiago $(0.2 \%$ of $449)$, chihuahua $(0.0 \%$ of 60$)$ or sao jorge $(0.0 \%$ of 66). However, the latter studies only analyzed SH/HC (Alcazar et al., 2006; Kongo et al., 2006; Prencipe et al., 2010). The prevalence of L. monocytogenes observed for Belgian artisanal cheeses in this survey was also higher than figure reported by European Food Safety Authority - European Centre for Disease Prevention and Control for European cheeses in 2018, i.e. $0.3 \%$ (European Food Safety Authority - European Centre for Disease Prevention and Control, 2019). More than 30,000 samples were considered by the latter report. In comparison, more than 200 times less samples were studied in this paper, which could explain the higher prevalence. Indeed, in case of reduced sampling size, a single contaminated cheese has an increased impact on the percentage. In 2018, 247 artisanal cheese producers were listed in Belgium. By collecting samples in 65 factories, around one out of four cheese producers was concerned by the study. It could have been interesting to focus more on the production volume of each cheese subtype in order to properly take this factor into account when designing the sampling plan. Nevertheless, it seems important to focus on all types of cheeses found on the Belgian market, provided that they are susceptible to be contaminated by L. monocytogenes and eaten by consumers.

In the present survey, both contaminated samples were made from raw milk. However, a meta-analysis based on recent EFSA reports showed no significant differences in the occurrence of L.monocytogenes between cheeses produced from raw or pasteurized milk (Martinez-Rios \& Dalgaard, 2018). The contaminated $\mathrm{SH} / \mathrm{HC}$ sample was a saint-paulin-type uncooked pressed cheese produced by a farmer in a shared processing workshop. Enumerated L. monocytogenes levels were under $10 \mathrm{cfu} \cdot \mathrm{g}^{-1}$. The pathogen was not isolated from other cheeses produced in the same workshop. Ahypothesis could be that the bacterium was already present in raw milk or that it was transmitted to cheese during post-processing steps. Indeed, re-contamination during post-processing handlings or during ripening is a frequent transmission route (Schvartzman et al., 2011; Ibarra-Sanchez et al., 2017). Levels under the enumeration limit of method ISO 11290-2 (i.e. $<10 \mathrm{cfu} \cdot \mathrm{g}^{-1}$ ) have already been reported during prevalence studies on SH/HC (Gérard et al., 2018). During random controls performed in 2017 2018 by the Federal Agency for the Safety of the Food Chain, all identified contaminated $\mathrm{SH} / \mathrm{HC}$ presented L. monocytogenes levels under $10 \mathrm{cfu} \cdot \mathrm{g}^{-1}$ (unpublished results). Such a contamination at the beginning of the storage of a $\mathrm{SH} / \mathrm{HC}$ sample should not necessary be considered as a threat for food safety. Indeed, if the production process of some $\mathrm{SH} / \mathrm{HC}$, including cantal, is known to allow the growth of L.monocytogenes, the extended ripening period has an inhibiting effect on L. monocytogenes (Chatelard-Chauvin et al., 2015). During refrigerated storage, no growth was observed anymore in chihuahua, edam, gouda and manchego (Gérard et al., 2018). Nevertheless, as each cheese has its proper characteristics, further investigations should be performed to know the fate of L. monocytogenes in this sample, for instance using challenge-tests.

The second contaminated sample identified during this study was a mold-ripened soft cheese made from raw ovine milk. In this case, the artisanal producer bought milk from a dairy farmer and transformed it in its own workshop. Observed L. monocytogenes level was $4.68 \log _{10} \mathrm{cfu} \cdot \mathrm{g}^{-1}$. Such a high contamination is worrying regarding food safety but is not unprecedented for RSC (Thisted Lambertz et al., 2012; Bernini et al., 2013; Rakhmawati et al., 2013). For instance, levels of $4 \log _{10} \mathrm{cfu} \cdot \mathrm{g}^{-1}$ were identified in a RSC involved in a Canadian listeriosis outbreak, while levels up to 6 $\log _{10} \mathrm{cfu} \cdot \mathrm{g}^{-1}$ have been observed during an outbreak associated with Camembert in Norway (Johnsen et al., 2010; Gaulin et al., 2012). RSC are generally considered as the most risky cheeses regarding L. monocytogenes, due to their highly favorable $a_{w}$ and $\mathrm{pH}$, especially on their rind. For instance, $\mathrm{pH}$ higher than 7 has been reported on the surface of brie and camembert (Gérard et al., 2018). A contamination of cheese surface generally results from a transfer of L. monocytogenes during post-processing steps. Nevertheless, during this study, the contamination was identified in cheese core, meaning that this hypothesis was not the most suitable. Further investigations showed that the ovine milk used to produce this cheese contained $3.48 \log _{10} \mathrm{cfu} \cdot \mathrm{ml}^{-1}$ of L. monocytogenes. Milk was analyzed again one week later and was not contaminated anymore. 


\section{CONCLUSIONS}

Given that most Belgian artisanal cheeses have $\mathrm{pH}>$ 4.4 and/or $a_{w}>0.92$, they should be considered as allowing L. monocytogenes to grow, following Regulation (EC) No 2073/2005. Nevertheless, it is known that other factors can inhibit its growth in cheese, including concentration of organic acids and endogenous microflora, with some species producing antimicrobial compounds like bacteriocins. Each cheese has its own chemicophysical and microbiological characteristics. In order to avoid the intense pressure on Belgian cheese producers in case of detection of L. monocytogenes, further studies should be implemented, including challenge-tests. The goal of such an experiment is to know the fate of L. monocytogenes in artificially contaminated cheese samples. The initial contamination should be $100 \mathrm{cfu} \cdot \mathrm{g}^{-1}$. Samples are stored in the fridge until the end of shelf-life. The pathogen is then enumerated and a growth potential can be calculated by comparing levels at the end of shelf-life and at the beginning of the storage. If the growth potential is lower than or equal to $0.5 \log _{10} \mathrm{cfu}^{\mathrm{g}} \mathrm{g}^{-1}$, cheese is considered as not suitable for the growth of L. monocytogenes (category 1.3 from Regulation (EC) No 2073/2005). Levels up to $100 \mathrm{cfu} \cdot \mathrm{g}^{-1}$ are then tolerated before cheese is put in the market, decreasing pressure on artisanal producers. However, despite this tolerance, good hygiene practices and Hazard Analysis and Critical Control Points still have to be applied in order to minimize the presence of L. monocytogenes in cheeses and workshops.

\section{Bibliography}

Agriculture et Agroalimentaire Canada, 2018. Analyse sectorielle - tendances dans le secteur des fromages en Europe de l'Ouest, http://www.agr.gc.ca/fra/industriemarches-et-commerce/renseignements-sur-les-marchesinternationaux-de-lagroalimentaire/rapports/analysesectorielle-tendances-dans-le-secteur-des-fromages-eneurope-de-l-ouest/?id=1535392086106, (21/08/19).

Alcazar M.C.D. et al., 2006. Detection of Salmonella spp. and Listeria monocytogenes in fresh and semi-cured cheeses that are sold on the street markets in Mexico City. Vet. Mexico, 37, 417-429.

Bernini V. et al., 2013. The presence, genetic diversity and behaviour of Listeria monocytogenes in blue-veined cheese rinds during the shelf-life. Food Control, 57, 1519, doi.org/10.1016/j.foodcont.2013.04.015

Brown S.R.B. et al., 2018. Acidification of model cheese brines to control Listeria monocytogenes. J. Food Prot., 81, 79-83, doi.org/10.4315/0362-028X.JFP-17-325

Chatelard-Chauvin C. et al., 2015. Behaviour of Listeria monocytogenes in raw milk Cantal type cheeses during cheese making, ripening and storage in different packaging conditions. Food Control, 54, 53-65, doi. org/10.1016/j.foodcont.2015.01.007

Codex Alimentarius, 2006. CODEX STAN A-6-1978 Codex General Standard for cheese, http://www. fao.org/fao-who-codexalimentarius/sh-proxy/ en/?lnk=1\&url=https\%253A\%252F\%252Fworkspace. fao.org $\% 252 \mathrm{Fsites} \% 252 \mathrm{~F}$ codex $\% 252 \mathrm{FStandards} \% 252$ FCODEX\%2BSTAN\%2B283-1978\%252FCXS_283e. pdf, (17/05/19).

European Commission, 2005. Commission Regulation No 2073/2005 of $15^{\text {th }}$ November 2005 on microbiological criteria for foodstuffs. Off. J. Eur. Union, L33, 1-26.

European Food Safety Authority - European Centre for Disease Prevention and Control, 2019. The European union summary report on trends and sources of zoonoses, zoonotic agents and food-borne outbreaks in 2017. EFSA J., 17, 5926, doi.org/10.2903/j.efsa.2018.5500

Ferreira V. et al., 2014. Listeria monocytogenes persistence in food-associated environments: epidemiology, strain characteristics, and implications for public health. J. Food Prot., 77, 150-170, doi.org/10.4315/0362-028X. JFP-13-150

Gaulin C. et al., 2012. Widespread listeriosis outbreak attributable to pasteurized cheese, which led to extensive cross-contamination affecting cheese retailers, Quebec, Canada, 2008. J. Food Prot., 75, 71-78, doi. org/10.4315/0362-028X.JFP-11-236

Gérard A. et al., 2018. Prevalence and survival of Listeria monocytogenes in various types of cheese - a review. Int J. Dairy Technol., 71, 825-843, doi.org/10.1111/14710307.12552

Gobbetti M. et al., 2018. The cheese of Italy: science and technology. New York, NY, USA: Springer.

Goudédranche H. et al., 2001. Procédés de transformation fromagère (partie 1). Techn. Ing., F6305.

Ibarra-Sanchez L.A. et al., 2017. Invited review: hispanicstyle cheeses and their association with Listeria monocytogenes.J.DairySci., 100, 1-12, doi.org/10.3168/ jds.2016-12116

International Organization for Standardization, 2006. ISO 5943:2006 cheese and processed cheese products determination of chloride content - potentiometric titration method. Geneva, Switzerland: ISO.

Johnsen B.O. et al., 2010. A large outbreak of Listeria monocytogenes infection with short incubation period in a tertiary care hospital. J. Infect., 61, 465-470, doi. org/10.1016/j.jinf.2010.08.007

Kongo J.M. et al., 2006. Detection and characterization of Listeria monocytogenes in Sao Jorge (Portugal) cheese production. J. Dairy Sci., 89, 4456-4461, doi. org/10.3168/jds.S0022-0302(06)72494-8

Larson A.E. et al., 1999. Survival of Listeria monocytogenes in commercial cheese brines. J. Dairy Sci., 82, 18601868, doi.org/10.3168/jds.S0022-0302(99)75419-6

Martinez-Rios V. \& Dalgaard P., 2018. Prevalence of Listeria monocytogenes in European cheeses: a 
systematic review and meta-analysis. Food Control, 84, 205-214, doi.org/10.1016/j.foodcont.2017.07.020

Prencipe V. et al., 2010. Assessment of hygienic quality of some types of cheese samples from retail outlets. Vet. Ital., 46, 233-242.

Rakhmawati T.W. et al., 2013. Statistical analysis of the Listeria monocytogenes EU-wide baseline survey in certain ready-to-eat foods. Part A: Listeria monocytogenes prevalence estimates. EFSA supporting publication. EFSA J., 11, 3241, doi.org/10.2903/ sp.efsa.2013.EN-441

Reda W.W. et al., 2016. Listeria monocytogenes: an emerging food-borne pathogen and its public health implications. J. Infect. Dev. Country, 10, 149-154, doi. org/10.3855/jidc.6616

Schvartzman M.S. et al., 2011. Effect of pH and water activity on the growth limits of Listeria monocytogenes in a cheese matrix at two contamination levels. J. Food Prot., 74, 1805-1813, doi.org/10.4315/0362-028X.JFP11-102
Soto Beltran M. et al., 2015. Prevalence and characterization of Listeria monocytogenes, Salmonella and Shiga toxinproducing Escherichia coli isolated from small Mexican retail markets of queso fresco. Int. J. Environ. Health Res., 25, 140-148, doi.org/10.1080/09603123.2014.915 016

Thisted Lambertz S. et al., 2012. Prevalence and level of Listeria monocytogenes in ready-to-eat foods in Sweden 2010. Int. J. Food Microbiol., 160, 24-31, doi. org/10.1016/j.ijfoodmicro.2012.09.010

Torres-Vitela M.R. et al., 2012. Incidence of Salmonella, Listeria monocytogenes, Escherichia coli O157:H7, and staphylococcal enterotoxin in two types of Mexican fresh cheeses. J. Food Prot., 75, 79-84, doi.org/10.4315/0362028X.JFP-11-258

(26 ref.) 